\title{
Laboratory Investigation of Plough Sole Reformation in a Simulated Paddy Field
}

\author{
Chen-Wuing Liu'; Wei-Sheng Yü; Wen-Teng Chen ${ }^{3}$; and Shih-Kai Chen ${ }^{4}$
}

\begin{abstract}
The study aimed to determine the number of cultivation cycles required to reform the plough sole once it has been destroyed or removed from the paddy. An ad hoc infiltration column experiment, which is a cylinder of $50 \mathrm{~cm}$ in diameter and $140 \mathrm{~cm}$ long, was setup to simulate the processes of ploughing and compaction, the two major forces exerted by a tractor, for developing a plough sole in rice paddy. Three experimental conditions were investigated, namely developing the plough sole by ploughing, compaction, and a combination of ploughing and compaction. The results of the change in the infiltration rate, soil dry bulk density, and weight percentage of clay in an experimental soil column were measured and evaluated. The experimental results show that, the infiltration rate decreases to 63,29 , and $2 \%$ of its initial value with ploughing eight times, compaction 30 times, and combination of ploughing and compaction 14 times, respectively. Moreover, the soil bulk density increases from 1.51 to $1.53,1.61$, and $1.71 \mathrm{~g} \mathrm{~cm}^{-3}$, respectively. Finally, the weight percentage of clay in the plough sole as a result of clay particles moving down from above and increases from 6.2 to 8.2, 6.2, and 14.8\%, respectively, over the experimental period. The ploughing rearranged clay content distribution and the compaction increased soil bulk density. Applying these two practices in sequence effectively increased the soil bulk density and reduced the infiltration rate. The results also indicate that after 14 ploughing and compaction the infiltration rate did not further decrease, suggesting that the soil structure could no longer be changed and the plough sole had successfully been reformed. The quantitative result of this work provides valuable information on how to rehabilitate a plough sole once it has been destroyed and needs to be reformed from the paddy field.
\end{abstract}

DOI: 10.1061/(ASCE)0733-9437(2005)131:5(466)

CE Database subject headings: Soil compaction; Infiltration rate; Laboratory tests; Layered soils.

\section{Introduction}

Over the past 20 years rapid economic growth, westernization, and rising living standards have significantly changed eating habits in Taiwan. Annual rice consumption per person has decreased from 101 to $57 \mathrm{~kg}$ during the past 20 years (COA 2000). In fact, overproduction of rice has become a major agricultural problem in Taiwan. Furthermore, having entered the World Trade Organization (WTO) Taiwan will certainly begin to import high quality and low cost rice. Consequently, a substantial reduction in paddy field acreage in Taiwan is imminent. The government has encouraged farmers to stop growing rice

\footnotetext{
${ }^{1}$ Professor, Dept. of Bioenvironmental Systems Engineering, National Taiwan Univ., Taipei, Taiwan 106, ROC (corresponding author). E-mail: lcw@gwater.agec.ntu.edu.tw

${ }^{2}$ Associate Professor, Dept. of Finance, Chungyu Institute of Technology, Keelung, Taiwan 201, R.O.C. E-mail: wsyu@ cit.edu.tw

${ }^{3}$ Master of Science, Dept. of Bioenvironmental Systems Engineering, National Taiwan Univ., Taipei, Taiwan 106, ROC.

${ }^{4}$ Researcher, Chi-Seng Water Management Research and Development Foundation, Taipei, Taiwan 106, ROC. E-mail: chensk@ chiseng.org.tw

Note. Discussion open until March 1, 2006. Separate discussions must be submitted for individual papers. To extend the closing date by one month, a written request must be filed with the ASCE Managing Editor. The manuscript for this paper was submitted for review and possible publication on November 21, 2003; approved on December 21, 2004. This paper is part of the Journal of Irrigation and Drainage Engineering, Vol. 131, No. 5, October 1, 2005. (CASCE, ISSN 0733-9437/2005/ $5-466-473 / \$ 25.00$.
}

and evaluates alternative uses of paddy land (Tzia 2000). Since flooded paddy can be viewed as an artificial wetland and a source of groundwater recharge, some parties have suggested the conversion of unplanted rice paddies to shallow ponds by increasing the bund height and removing the less permeable plough sole to increase the infiltration rate and boost groundwater recharge. It is widely known that ploughing and compaction can gradually form an impermeable plough sole in a rice paddy. Once the plough sole is removed, the time or the number of cultivation practices required to reform the plough sole remains uncertain, and thus careful examination is required before converting existing paddy fields in accordance with the above proposal.

The study aims to quantitatively assess plough sole reformation following its removal from the paddy, using ploughing and compaction. A laboratory experiment was designed to simulate the ploughing and compaction. Specifically, the infiltration rate associated with various repetitions of ploughing, compaction, or combined ploughing and compaction, was recorded. Also, the change in weight percentage of clay content and soil bulk density along the upper soil layer were also measured following each experiment. The number of ploughing and compaction required to restore the plough sole in a paddy field was determined based on the measured soil bulk density and clay content, and the estimated hydraulic conductivity of the plough sole. The experimental results can assist the government in formulating a policy of replenishing groundwater in unplanted rice paddy fields and enhancing the ecological and environmental conservation functions of paddies in Taiwan. 


\section{Plough Sole Formation}

The plough sole layer is generally found $20-40 \mathrm{~cm}$ below the soil surface with a thickness of $5-10 \mathrm{~cm}$ in Taiwan (Liu et al. 2001; Chen and Liu, 2002). Ploughing, harrowing, and leveling the saturated soil create the plough sole. Puddling destroys soil aggregates, reduces macropores, and increases micropores (De Datta 1981; Sharma and De Datta 1985). In addition, settling and consolidation of dispersed clay particles may occur when puddling. Both compaction and clay translocation create a zone of lower hydraulic conductivity known as plough sole or hardpan. The plough sole has a higher dry bulk density and lower hydraulic conductivity, and can be easily identified through observation of the profile of a soil sample (Wopereis et al. 1992, 1994; Iwata et al. 1995; Liu and Chen 1998; and Ting et al. 1998). Wopereis et al. (1992) suggested that plough soles are located beneath plough layers that have a significantly reduced hydraulic gradient. In general, the ploughing depth is less than $50 \mathrm{~cm}$. Thus the location of plough sole is within $1 \mathrm{~m}$ of the shallow soil. Ting et al. (1998) surveyed the distribution of plough sole in Mei-Noum and Tar-Lau counties of Taiwan extensively and ascertained that the plough sole was $25 \mathrm{~cm}$ below the surface soil, and had a thickness that ranged from 4 to $8 \mathrm{~cm}$, as well as a higher bulk density. Chen and Liu (2002) reported that in Ten-Chung county of Taiwan the plough sole thickness was $7.5 \mathrm{~cm}$.

In paddy fields, during the puddling process, the soil is submerged under standing water for 2-10 days to promote soil chemical reduction, reduce soil mechanical strength, and hence reduce the force and energy needs for the puddling tillage. Two forces are applied to the soil during puddling: one is ploughing to loosen and break soils and the other is compaction of the soil (Ghidyal 1978). The ploughing may disperse the fine particles and ultimately clog the soil pore space. The clogging process is similar to filtration. Three mechanisms may be involved in filtration including surface cake filtration, strain filtration, and physicalchemical filtration (Sakthivadivel 1969; Herzig et al. 1970; Sherard et al. 1984; McDowell-Boyer et al. 1986). If the soil particle moves into pore space and is retarded by shear stress among other particles it is called strain filtration. Moreover if the particle is small enough to be adsorbed onto the particle surface by surface reaction and removed from the flow stream, it is called physicalchemical filtration. If a large soil particle fails to pass through the pore and then deposit on the soil surface area, it is called surface cake filtration.

If the soil texture is not uniform and contains a certain amount clay particles, it is easy to develop plough sole by strain and physical-chemical filtrations. For example, Curfs (1976) found an incipient plough sole formation in fine sandy loams in Nigeria, after 3 years of mechanized wet-rice preparation (Moormann and Van Breemen 1978). If the percentage of clay in soil texture is too high, it is not suitable for developing plough sole because the surface cake filtration becomes the dominant mechanism. For example, in polder lands of the Shiroishi area, Kyushu Japan, with fine clayey sediments, no plough sole formation was observed after 10-12 years of rice culture but incipient plough soles formed after 50 years, and well developed plough soles after more than 200 years (Moormann and Van Breemen 1978). Furthermore, a sandy soil with no clay content will not form a plough sole.

The agricultural machine's wheels create a compression beneath the puddled soils and expel gas bubbles and water from the unsaturated and saturated soil, respectively, and gradually
Table 1. Clay Contents of Soil Samples in Ten-Chung Paddy Field

\begin{tabular}{lccc}
\hline Sample number & & $\begin{array}{c}\text { Depth } \\
(\mathrm{cm})\end{array}$ & $\begin{array}{c}\text { Weight percentage } \\
\text { of clay content }^{\mathrm{a}}\end{array}$ \\
\hline I & 1 & $0-20$ & 4.1 \\
& 2 & $0-20$ & 4.7 \\
& 3 & $0-20$ & 4.3 \\
II & & & \\
& 1 & $20-25$ & 5.3 \\
& 2 & $20-25$ & 3.6 \\
& 3 & $20-25$ & 4.6 \\
III & & & 9.5 \\
& 1 & $25-30$ & 10.8 \\
& 2 & $25-30$ & 9.0 \\
& 3 & $25-30$ & 8.7 \\
IV & & & 9.7 \\
& 1 & $30-60$ & 10.3 \\
\hline
\end{tabular}

${ }^{\mathrm{a}}$ Particle size $<0.002 \mathrm{~mm}$.

increase the soil bulk density (Swan et al. 1993). Ghildyal and Satyanarayana (1965) conducted a compaction experiment on a lateritic sandy clay loam soil. The soil bulk density increased from 1.53 to $1.83 \mathrm{~g} \mathrm{~cm}^{-3}$ and the hydraulic conductivity decreased from 35.64 to $2.52 \mathrm{~cm} \mathrm{~h}^{-1}$. It was evident that compaction increased the soil bulk density as well as decreased the infiltration rate. But the number of ploughing and compaction required to form the impermeable plough sole was not known.

\section{Materials and Methods}

\section{Soil Property}

Feng et al. $(1995,1996)$ investigated the soil properties in ChiaNan plain of Taiwan and showed that the infiltration capacities of the plough sole were reduced to 10 and $50 \%$ of the original one in silty and sandy soils, respectively. Plough sole develops poorly in sandy soil. That is, since a sandy soil does not have enough clay content, the cultivation practices may not form an impermeable plough sole. It is necessary to obtain the range of clay content in a typical paddy rice field before preparing the experimental soil column. Ten-Chung, situated upstream of the Chou-Shui river alluvial fan, is a major rice production area of Taiwan which has been cultivated over 200 years since the Ching Dynasty. Soil samples were thus collected by a hand auger to $60 \mathrm{~cm}$ in depth at Ten-Chung. The percentage of clay content ranges from 3.6 to $10.8 \%$ (Table 1). These data provide a guideline for choosing the type of soil with suitable ranges of clay content used in preparing the experimental column.

Table 2. Experimental Soil Texture

\begin{tabular}{lccc}
\hline Classification & $\begin{array}{c}\text { Particle diameter } \\
(\mathrm{mm})\end{array}$ & $\begin{array}{c}\text { Kaolinite } \\
(\%)\end{array}$ & $\begin{array}{c}\text { Quartz sand } \\
(\%)\end{array}$ \\
\hline Sand & $>0.05$ & 24.1 & 94.1 \\
Silt & $0.05-0.002$ & 22.5 & 4.4 \\
Clay & $<0.002$ & 53.4 & 1.5 \\
\hline
\end{tabular}


Table 3. Experimental Conditions and Measured Properties

\begin{tabular}{|c|c|c|c|c|c|c|c|}
\hline \multirow[b]{2}{*}{ Case } & \multirow{2}{*}{$\begin{array}{c}\text { Mixed } \\
\text { soil thickness } \\
(\mathrm{cm})\end{array}$} & \multirow{2}{*}{$\begin{array}{c}\text { Kaolinite: } \\
\text { quartz sand ratio } \\
\text { of mixed soil }\end{array}$} & \multicolumn{3}{|c|}{$\begin{array}{l}\text { Initial texture of } \\
\text { mixed soil }(\%)\end{array}$} & \multirow[b]{2}{*}{ Applied practices } & \multirow[b]{2}{*}{ Measured items } \\
\hline & & & Sand & Silt & Clay & & \\
\hline $\mathrm{C} 1$ & 30 & $1: 10$ & 87.7 & 6.0 & 6.2 & Compaction & Infiltration rate, bulk density \\
\hline $\mathrm{P} 1$ & 30 & $1: 10$ & 87.7 & 6.0 & 6.2 & Ploughing & Infiltration rate, bulk density, soil texture \\
\hline P2 & 30 & $1: 21.5$ & 91.0 & 5.2 & 3.8 & Ploughing & Infiltration rate \\
\hline P3 & 5 & $1: 5$ & 82.4 & 7.4 & 10.2 & Ploughing & Bulk density, soil texture \\
\hline $\mathrm{CP} 1$ & 30 & $1: 10$ & 87.7 & 6.0 & 6.2 & $\begin{array}{l}\text { Ploughing and } \\
\text { Compaction }\end{array}$ & Infiltration rate, bulk density, soil texture \\
\hline
\end{tabular}

Two types of soils were used for the experiment: low clayey quartz sand and high kaolinite clay. The kaolinite does not swell upon wetting. The quartz sand contains $99 \% \mathrm{SiO}_{2}$ with a median grain size of $0.075 \mathrm{~mm}$. The kaolinite, with a median grain size of $0.0075 \mathrm{~mm}$, contains $85 \%$ of $\mathrm{SiO}_{2}$ and $\mathrm{Al}_{2} \mathrm{O}_{3}$. Table 2 lists the texture of the two soil types. Mixed soils of quartz sand to kaolinite ratios of $10: 1,5: 1$, and $21.5: 1$ by weight were prepared to form the upper soil column for study of the reformation of plough sole. The initial texture of mixed soils is given in Table 3 and the percentage of clay content was within the range of measured values in the paddy field.

\section{Infiltrometer}

The infiltrometer contains four components: water supply system, infiltration column, groundwater table controlling tank, and out- flow measurement unit (Fig. 1). The water supply system consists of a water head controlling tank and storage tank in which the submersible motor can pump water from the storage tank to the water head controlling tank. An overflow discharge pipe maintains a constant water level in the water head-controlling tank. The bottom of this tank has a control valve that supplies water into the infiltration column, which is a cylinder of $50 \mathrm{~cm}$ in diameter and $140 \mathrm{~cm}$ long, made from $1 \mathrm{~cm}$ thick acrylate. To maintain a $10 \mathrm{~cm}$ flooded water depth, a lateral hole of the infiltration column connects to an overflow pipe which discharges water to the storage tank. A constant flooded water depth simplifies the balance of water mass in the soil column. Five plastic tubes connect the bottom of the infiltration column to the groundwater table controlling tank. The controlling tank maintains a constant groundwater table. The effluent water is collected in a

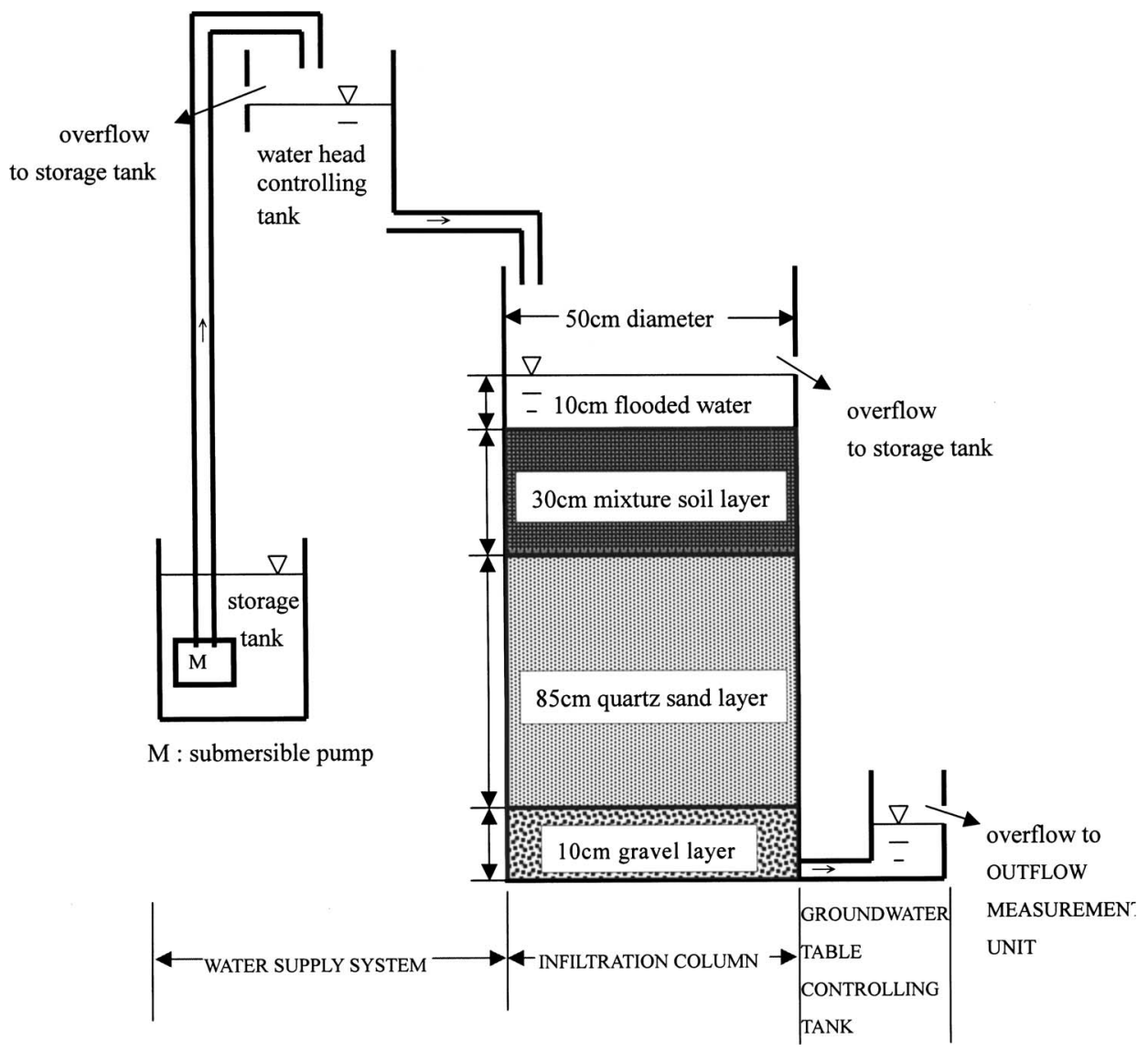

Fig. 1. Schematic of laboratory experiment setup (not to scale) 
closed tank and measured by an electronic balance. A nonwoven fabric sheet was placed on the bottom of the infiltration column below the gravel layer to prevent the soil particles from leaking out.

A large uniform compactor consisting of a $5.4 \mathrm{~kg}$ large compaction hammer and a compaction plate with a $50 \mathrm{~cm}$ diameter was used to compact the soil at a $5 \mathrm{~cm}$ depth interval. The compaction hammer was dropped from $75 \mathrm{~cm}$ height three times until the soil column stopped subsidizing. Also, a $5 \mathrm{~cm}$ long iron plate with two teeth was used to simulate the ploughing equipment in a paddy. Each tooth is $0.5 \mathrm{~cm}$ wide and $3 \mathrm{~cm}$ long welded on the iron plate which can plow over $20 \%$ of the soil surface in each operation. Notably, the iron plough loosens soil horizontally and does not flick soil particles vertically. Consequently, a $5 \mathrm{~cm}$ long flattening vertical plate with an adjustable height was used to level the soil surface three times. To simulate the compaction resulting from the wheel load of an agricultural machine during cultivation, a small compactor having a $2.2 \mathrm{~kg}$ compaction hammer and $22 \mathrm{~cm}$ diameter compaction plate with five equally sized rectangular blocks $(5 \mathrm{~cm} \times 5 \mathrm{~cm} \times 7 \mathrm{~cm})$ attached to the bottom was used. Notably, a mechanical plough weighs around $1,000 \mathrm{~kg}$. Assuming the surface contact area of the four wheels is $0.3 \mathrm{~m}$ $\times 0.15 \mathrm{~m} \times 4=0.18 \mathrm{~m}^{3}$, the paddy soil surface experienced a $5,556 \mathrm{~kg} \mathrm{~m}^{-2}$ pressure from a tractor. Here, the force applied to the surface area was $0.05 \mathrm{~m} \times 0.05 \mathrm{~m} \times 5=0.0125 \mathrm{~m}^{2}$, while a falling height of $0.32 \mathrm{~m}$ and soil subsidence which was measured before and after 50 ploughing and compaction cultivation cycles of approximately $1 \mathrm{~cm}$ were assumed. Accordingly, the average (not the peak) pressure applied to the soil surface by the compactor is

$$
p=\frac{2.2 \mathrm{~kg} \times 0.32 \mathrm{~m}}{\left(0.0125 \mathrm{~m}^{2}\right) \times 0.01 \mathrm{~m}}=5,632 \mathrm{~kg} \mathrm{~m}^{-2}
$$

The experimental pressure applied to the soil surface of the column is close to that applied to the paddy field by the ploughing tractor.

\section{Soil Column Preparation}

The soil column profile from top to bottom is a $30 \mathrm{~cm}$ mixed soil, followed by a $85 \mathrm{~cm}$ quartz sand, and a $10 \mathrm{~cm}$ gravel layer underneath (Fig. 1). Furthermore, the contrast hydraulic conductivities between quartz sand and mixed soil reveal in situ condition of the Ten-Chung rice paddy. The flooded water depth is maintained at $3 \mathrm{~cm}$ or $10 \mathrm{~cm}$ above the soil surface, whereas the groundwater table is set at $8 \mathrm{~cm}$ from the bottom of the soil column.

The experimental soil column is first prepared by applying vaseline to the side wall of the infiltration column thoroughly to prevent seepage, and then a gravel layer of $10 \mathrm{~cm}$ thickness is placed at the bottom. A flat plate is used to level the layer surface while the air is removed from the column. A fixed amount of soil and water is weighed, and mixed homogeneously. The water/soil mixture of $5 \mathrm{~cm}$ thickness is added in the infiltration column and leveled with the flat plate. After the soil column is compacted, the soil surface is brushed to create a rough surface and to improve the contact of soil particles. Once it is accomplished, another soil/water mixture of $5 \mathrm{~cm}$ thickness is added, leveled, and compacted in the column repeatedly until the soil column is completely prepared.

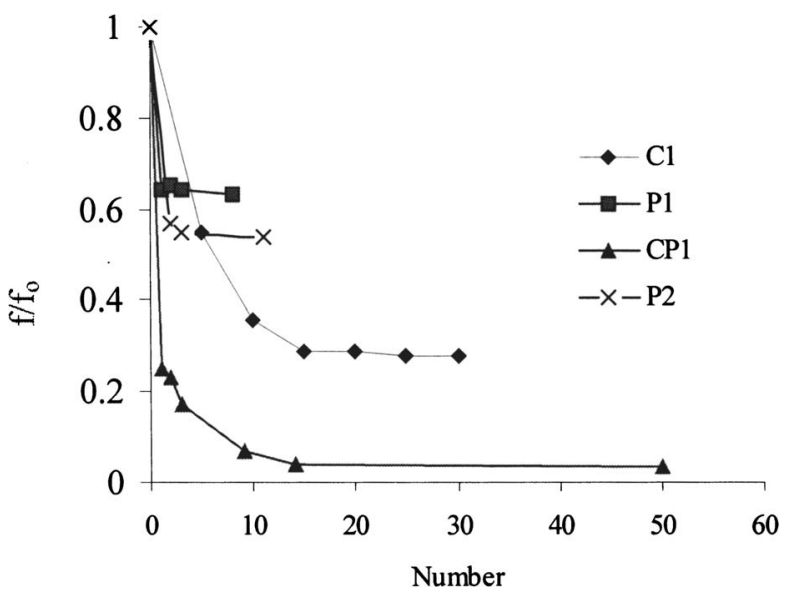

Fig. 2. Infiltration rate normalized with respect to initial infiltration rate versus number of applied practice

\section{Experimental Procedures}

In the beginning, a flooded water depth of $10 \mathrm{~cm}$ is maintained for 4 days to saturate the water content in the soil column. Air bubbles are expelled out the soil column bottom. A groundwater table controlling tank is used to maintain $8 \mathrm{~cm}$ height (less than the $10 \mathrm{~cm}$ thick gravel layer). The infiltration rate, evaporation rate, and ambient temperature are measured subsequently. The flooded water of $10 \mathrm{~cm}$ is then siphoned from the soil column. After that, ploughing, compaction, or combination of ploughing and compaction is applied to the soil column. The flooded water depth is first maintained at $3 \mathrm{~cm}$, followed by ploughing with the two-tooth iron plough. After waiting $30 \mathrm{~min}$ to allow the suspended particles to settle into pore space, a flattened plate is applied to level the soil surface. The soil is compacted if necessary. After completing a cultivation cycle, the flooded water depth of $10 \mathrm{~cm}$ is added and the infiltration rate is measured. The ploughing, compaction, or combination of ploughing and compaction cultivation cycle is repeated until the infiltration rate no longer decreases. After the experiment is finished, the top $20 \mathrm{~cm}$ of water in the soil column drains out. Five soil layer samples at depths of $0-3,3-5,5-7,7-9$, and 9-11 $\mathrm{cm}$ are sliced. The dry bulk density and clay content percentage of each sliced soil sample are measured accordingly.

\section{Experimental Sets}

Five sets of experiments were conducted under the same flooded water depth, groundwater table, gravel layer thickness, quartz sand thickness, and ploughing depth. Table 3 lists the experimental conditions and measured items. The symbols $\mathrm{C}$ and $\mathrm{P}$ denote the compaction and ploughing applied to the soil column, respectively, and the CP symbol represents applying the ploughing first, followed by a compaction.

The mixed soil thickness was $30 \mathrm{~cm}$ except for the P3 experiment in which the thickness was $5 \mathrm{~cm}$. The texture of mixed soils of $\mathrm{P} 1, \mathrm{P} 2$, and $\mathrm{P} 3$ were prepared differently for comparison.

To evaluate the individual effect of ploughing, compaction, and combination of ploughing and compaction, infiltration rates were measured separately for the applied cultivation practices, viz. ploughing, compaction, or combination of ploughing and compaction. If an increase in the cultivation practices did not decrease the infiltration rate, the number of the cultivation practices was recorded. This represents the minimum cultivation 


\begin{tabular}{|c|c|c|c|c|c|c|c|c|}
\hline \multirow[b]{2}{*}{ Case } & \multirow{2}{*}{$\begin{array}{l}\text { Number } \\
\text { of applied } \\
\text { practices }\end{array}$} & \multicolumn{2}{|c|}{$\begin{array}{l}\text { Infiltration rate } \\
\qquad\left(\mathrm{cm} \mathrm{h}^{-1}\right)\end{array}$} & \multirow[b]{2}{*}{ Position $(\mathrm{cm})$} & \multicolumn{2}{|c|}{$\begin{array}{l}\text { Soil bulk density } \\
\qquad\left(\mathrm{g} \mathrm{cm}^{-3}\right)\end{array}$} & \multicolumn{2}{|c|}{$\begin{array}{l}\text { Weight percentage } \\
\text { of clay content } \\
(\%)\end{array}$} \\
\hline & & Initial & Final & & Initial & Final & Initial & Final \\
\hline $\mathrm{C} 1$ & 30 & 2.04 & 0.58 & $0-5$ & 1.51 & 1.61 & 6.2 & 7.1 \\
\hline $\mathrm{P} 1$ & 8 & 2.03 & 1.28 & $7-9$ & 1.51 & 1.53 & 6.2 & 8.2 \\
\hline P2 & 11 & 6.58 & 3.58 & - & - & - & - & - \\
\hline P3 & 8 & - & - & $5-7$ & 1.40 & 1.66 & 1.5 & 18.9 \\
\hline \multirow[t]{2}{*}{$\mathrm{CP} 1$} & 1 & 2.04 & 0.51 & $5-7$ & 1.51 & 1.60 & 6.2 & 9.4 \\
\hline & 14 & 2.04 & 0.04 & $3-5$ & 1.51 & 1.71 & 6.2 & 14.8 \\
\hline
\end{tabular}

cycles that is required to reform the plough sole in the paddy once it has been removed. The soil column was then sliced to obtain five samples and the dry bulk density and clay content were measured to compare with the properties of a plough sole in the paddy field.

\section{Results and Discussion}

\section{Infiltration Rate}

Fig. 2 displays the normalized infiltration rate versus the number of applied practices of four experimental sets. The normalized infiltration rate is defined as the ratio of the infiltration rate at the number of applied cultivation practices $(f)$ to the initial infiltration rate. The $f_{0}$ is the initial infiltration rates measured before the experiment. The $f_{0}$ of $\mathrm{C} 1, \mathrm{P} 1$, and $\mathrm{CP} 1$ ranged from 2.03 to $2.04 \mathrm{~cm} \mathrm{~h}^{-1}$, whereas $f_{0}$ of $\mathrm{P} 2$ is $6.58 \mathrm{~cm} \mathrm{~h}^{-1}$. As the number of treatments increased, the infiltration rate gradually reduced and eventually reached a constant value. Table 4 lists the number of applied practices as the final constant infiltration rate is reached.

The initial clay contents of P1 and P2 mixed soils were 6.2 and $3.8 \%$, respectively, and the corresponding initial infiltration rate ratio of $\mathrm{P} 1-\mathrm{P} 2$ was $30 \%$. As the number of ploughing practices increased, the infiltration rate of P2 decreased much faster than that of P1. It suggests that as the clay particles, which are subject to strain and physical-chemical filtrations move downward and deposit on the large pore space of $\mathrm{P} 2$, the infiltration rate significantly reduces. The initial and final infiltration rates of all experimental sets are listed in Table 4.

The mixed soils for treatments $\mathrm{P} 1, \mathrm{C} 1$, and $\mathrm{CP} 1$ were prepared to have the same soil texture. The infiltration rates of P1 and C1 were reduced to 63 and $29 \%$ of its initial value after ploughing eight times and compacting 30 times. However, the infiltration rate of $\mathrm{CP} 1$ was reduced to 25 and $2 \%$ of its initial value after ploughing and compacting one and 14 times, respectively. It is clear that the combination of ploughing and compaction can reduce the infiltration rate more than just ploughing or compaction. Ploughing the top $5 \mathrm{~cm}$ surface soil dispersed the fine particles into $3 \mathrm{~cm}$ depth of flooded water. The experiment was left for $30 \mathrm{~min}$ to allow dispersed particles to set into the pore space. The soil was then compacted to complete one cultivation cycle. The ploughing rearranged clay content distribution and the compaction increased soil bulk density. Applying these two practices in sequence effectively increased the soil bulk density and reduced the infiltration rate. The results also indicate that after 14 ploughing and compactions the infiltration rate did not further decrease, suggesting that the soil structure could no longer be changed and the plough sole had successfully been reformed.

\section{Soil Dry Bulk Density}

Fig. 3 displays the soil bulk density profile of P1 and P3 and the percentage weight of clay of the P1 and P3 treatments after ploughing eight times. The bulk density of P1 only slightly increases from 1.51 to $1.53 \mathrm{~g} \mathrm{~cm}^{-3}$ at $7-9 \mathrm{~cm}$ below the soil surface. Moreover, ploughing had little influence on soil bulk density. The bulk density at $3-5 \mathrm{~cm}$ depth of P3 with a $5 \mathrm{~cm}$ thick mixed soil, decreased from 1.60 to $1.48 \mathrm{~g} \mathrm{~cm}^{-3}$ after ploughing, whereas the bulk density of the first $2 \mathrm{~cm}$ quartz sand layer underneath the mixed soil (or at $5-7 \mathrm{~cm}$ below the soil surface) increased from 1.40 to $1.66 \mathrm{~g} \mathrm{~cm}^{-3}$. The increase in the bulk density in the quartz sand layer is attributed to the redistribution of fine clay particles from the $5 \mathrm{~cm}$ thick mixed soil layer to the quartz sand layer. However the fine clay particles are impeded by the $30 \mathrm{~cm}$ thick layer of mixed soil in the case of P1 and cannot move to the quartz sand layer.

Fig. 4 illustrates the initial and final bulk density profile of $\mathrm{C} 1$ and CP1. The bulk densities of $\mathrm{C} 1$ after 30 compactions at depths

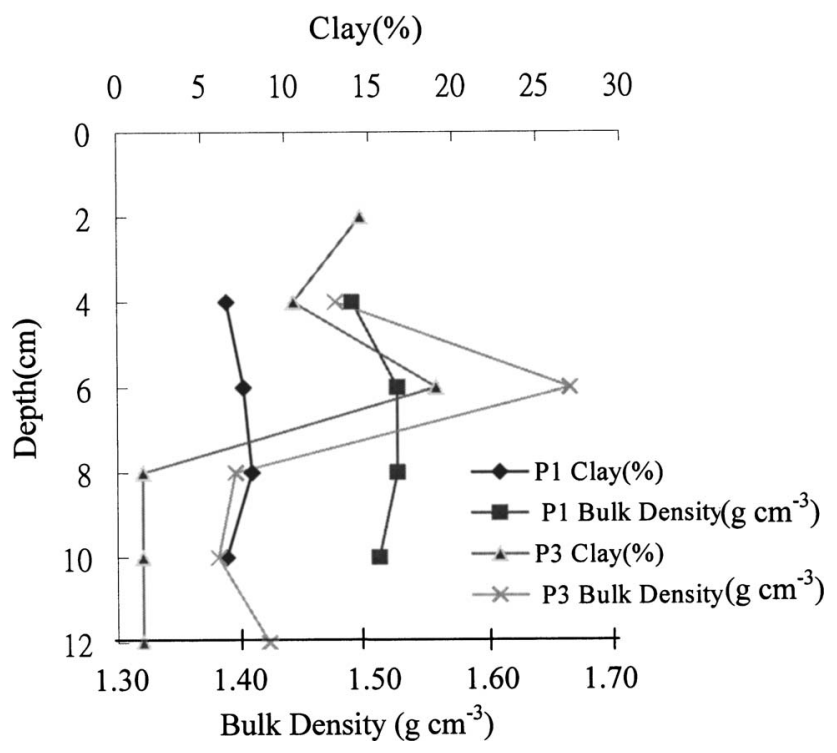

Fig. 3. Soil bulk density and percentage weight of clay content profile of P1 and P3 after ploughing eight times 


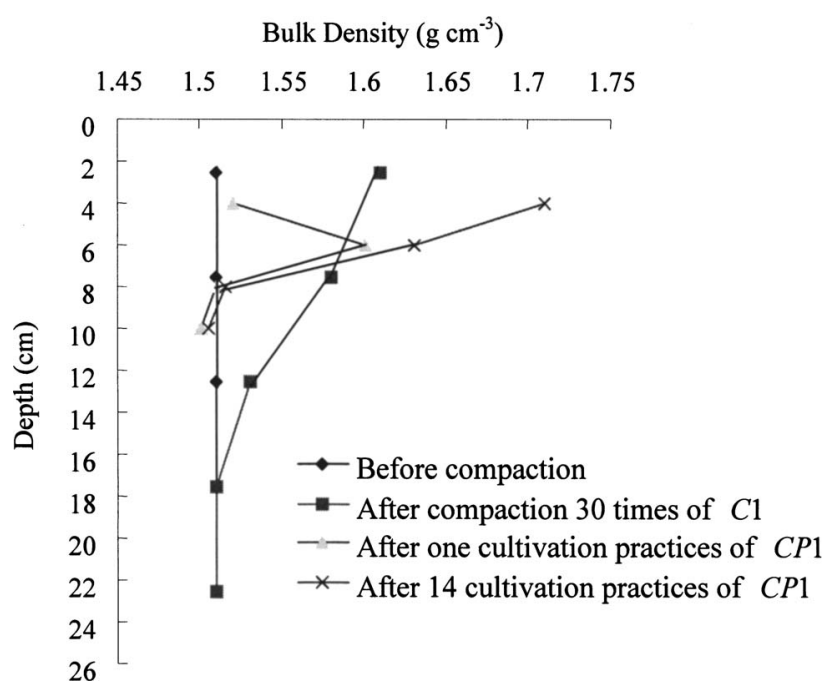

Fig. 4. Soil bulk density profile of $\mathrm{C} 1$ and $\mathrm{CP} 1$

of $0-5,5-10$, and $10-15 \mathrm{~cm}$ are $1.61,1.58$, and $1.53 \mathrm{~g} \mathrm{~cm}^{-3}$, respectively. The influence of compaction on bulk density decreases with increasing soil depth.

The result of $\mathrm{CP} 1$ reveals that by applying 14 repetitions of combined ploughing and compaction to the soil column, the soil bulk densities of $0-2 \mathrm{~cm}$ above and below the ploughing depth (5 $\mathrm{cm}$ measured from the soil surface) increased from 1.51 to $1.71 \mathrm{~g} \mathrm{~cm}^{-3}$ and 1.51 to $1.63 \mathrm{~g} \mathrm{~cm}^{-3}$, respectively. Following a single ploughing and compaction the highest bulk density was located at $0-2 \mathrm{~cm}$ below the ploughing depth, while after 14 ploughings and compactions, the highest bulk density was located at $0-2 \mathrm{~cm}$ above the ploughing depth. The translocation of the highest bulk density from below to above the ploughing depth is worth elucidating. Once ploughing and compaction have been repeated several times, a less permeable layer gradually forms below the ploughing depth, possibly preventing the fine clay particles from moving further downwards and hence causing them to accumulate above the ploughing depth. The zigzagged iron plough, used to simulate the ploughing equipment in the paddy field, could only loosen soil horizontally and did not invert soil particles vertically. The two-tooth iron plough differs from the field diesel powered rotary equipment, which vertically churns the soil particles and prevents the accumulation of fine particles at the bottom of ploughing depth. The impermeable plough sole generally appears below the ploughing depth in paddy fields.

The soil bulk densities were also measured at Ten-Chung paddy field (Table 5). Soils at depths of 20-30 cm were analyzed at the mid-point of the range to locate the plough sole. The largest

Table 5. Soil Bulk Density Profile in Ten-Chung Paddy Field

\begin{tabular}{lc}
\hline $\begin{array}{l}\text { Depth } \\
(\mathrm{cm})\end{array}$ & $\begin{array}{c}\text { Soil bulk density } \\
\left(\mathrm{g} \mathrm{cm}^{-3}\right)\end{array}$ \\
\hline $0-10$ & 1.33 \\
$20-22.5$ & 1.49 \\
$22.5-25$ & 1.50 \\
$25-27.5$ & 1.51 \\
$27.5-30$ & 1.53 \\
$30-40$ & 1.46 \\
$40-60$ & 1.42 \\
\hline
\end{tabular}

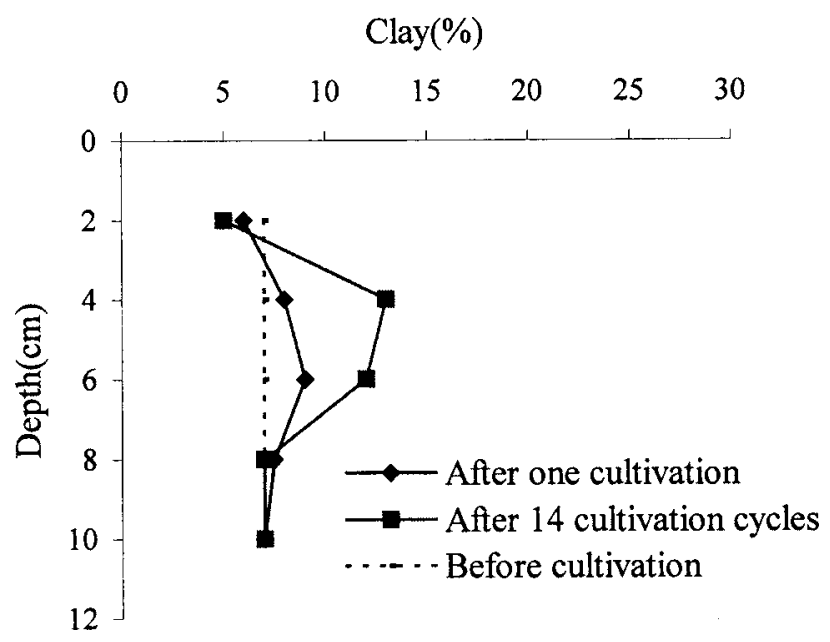

Fig. 5. Percentage weight of clay content profile of CP1 before and after combination of ploughing and compaction cultivation practices

bulk density was at $20-30 \mathrm{~cm}$ while the smallest bulk density occurred at $0-10 \mathrm{~cm}$. Four soil bulk densities at depths of $20-30 \mathrm{~cm}$ remained unchanged. Comparing the variation of soil bulk density profile of CP1 with the Ten-Chung paddy, even though the experimental soil mixture (CP1) with high initial bulk density yields a high final bulk density after the ploughing and compaction, the final soil bulk density profile of CP1 exhibits a similar shape as shown in the Ten-Chung paddy suggesting the experimental ploughing and compaction sufficiently represent the cultivation practice in the field paddy.

\section{Weight Percentage of Clay Content}

Fig. 3 shows that the highest weight percentage of clay content of P3 is $18.9 \%$. It is located $0-2 \mathrm{~cm}$ below the ploughing depth $(5 \mathrm{~cm})$. The original weight percentage of clay content of this quartz sand layer was $1.5 \%$ and the thickness of mixed soil layer was $5 \mathrm{~cm}$. The ploughing dispersed the fine clay particles which then settled into the pore space of the quartz sand layer by strain as well as by physical-chemical filtrations. However, the $30 \mathrm{~cm}$ thick mixed soil of P1 prevented the strain and physical-chemical filtrations, and hence the weight percentage of clay content only increased from 6.2 to $8.2 \%$. This increased clay was located 7-9 $\mathrm{cm}$ below the soil surface (Fig. 3). Compared to CP1 applying one ploughing and compaction, the weight percentage of clay content, as shown in Fig. 5, increases from 6.2 to $9.4 \% 0-2 \mathrm{~cm}$ below the ploughing depth and is higher than P1. If the ploughing and compaction were applied 14 times, the percentage weight of clay content increased from 6.2 to $14.8 \% 0-2 \mathrm{~cm}$ above the ploughing depth. It suggests that a less permeable zone was formed which prevented fine clay particles from entering into the deeper zone and accumulating in the bottom of the ploughing layer. The clay contents of the upper plough layer $(20-25 \mathrm{~cm})$

Table 6. Data Used to Estimate Hydraulic Conductivity of C1, P1, and $\mathrm{CP} 1$

\begin{tabular}{lccc}
\hline Case & $\begin{array}{c}Q \\
\left(\mathrm{~cm}^{-3} \mathrm{~min}\right)\end{array}$ & $\begin{array}{c}I \\
\left(\mathrm{~cm} \mathrm{~cm}^{-1}\right)\end{array}$ & $\begin{array}{c}A \\
\left(\mathrm{~cm}^{2}\right)\end{array}$ \\
\hline C1 & 20.03 & $30 / 30$ & 1963.5 \\
P1 & 42.66 & $30 / 30$ & 1963.5 \\
CP1 & 2.71 & $30 / 30$ & 1963.5 \\
\hline
\end{tabular}


Table 7. Comparison of Steady State Infiltration Rate and Hydraulic Conductivity

\begin{tabular}{lcccc}
\hline & Before experiment & C1 & P1 & CP1 \\
\hline Steady state infiltration rate $\left(\mathrm{cm} \mathrm{h}^{-1}\right)$ & 2.04 & 0.58 & 1.28 & 0.04 \\
Hydraulic conductivity $K\left(\mathrm{~cm} \mathrm{~s}^{-1}\right)$ & $5.71 \times 10^{-4}$ & $1.71 \times 10^{-4}$ & $3.61 \times 10^{-4}$ & $2.29 \times 10^{-5}$ \\
\hline
\end{tabular}

and the plough sole $(25-30 \mathrm{~cm})$ are approximately 4.5 and $9.8 \%$, respectively, or by a ratio of 2.2 in the Ten-Chung paddy which is close to the data of $\mathrm{CP} 1$ with a ratio of 2.4 (see Table 1 and Fig. 5). The result suggests that the laboratory experiment approximates well with the field condition in the Ten-Chung paddy.

The results indicate that the combination of ploughing and compaction effectively reduced the infiltration rate and also suggest that after ploughing and compacting to the soil column 14 times the plough sole was reformed. The weight percentage of clay content is the essential factor for formation of a less permeable zone. So long as clay particles remain in the paddy field without being cast away, the less permeable zone will be reformed after ploughing and compacting cultivation cycles soil 14 times.

\section{Hydraulic Conductivity}

The hydraulic conductivity of different experimental cases can be estimated by Darcy's law, represented in Eq. (2), based on the measured infiltration rate

$$
Q=K I A
$$

where $Q$ denotes the volumetric flux $\left[\mathrm{L}^{3} \mathrm{~T}^{-1}\right] ; K$ represents the hydraulic conductivity $\left[\mathrm{L} \mathrm{T}^{-1}\right] ; I=$ hydraulic gradient $\left[\mathrm{L} \mathrm{L}^{-1}\right]$; and $A$ denotes the cross section area $\left[\mathrm{L}^{2}\right]$. Table 6 lists the data used to estimate the hydraulic conductivity using Darcy's law of $\mathrm{C} 1, \mathrm{P} 1$, and CP1 following application of the corresponding practices. Moreover, the estimated hydraulic conductivity and the steady state infiltration rate are also compared (see Table 7). The hydraulic conductivity of $\mathrm{C} 1$ and $\mathrm{P} 1$ have the same order as that of the silty sand, whereas the hydraulic conductivity of CP1 is 1 order of magnitude smaller than the $\mathrm{C} 1, \mathrm{P} 1$, and silty sand. Additionally, the value of $\mathrm{CP} 1$ is 25 times smaller than the hydraulic conductivity measured before the experiment, suggesting an impermeable plough sole is indeed reformed after 14 cycles of ploughing and compaction.

\section{Conclusions and Suggestion}

Ploughing and compaction markedly reduce the infiltration rate and hydraulic conductivity, while increasing the soil bulk density and percentage weight of clay in soil. Ploughing and compaction 14 times decreased the infiltration rate to $2 \%$ of its initial value, whereas ploughing eight times or compaction 30 times individually reduced the infiltration rate to 63 and $29 \%$, respectively. Ploughing changed the weight percentage of clay particle content from 6.2 to $8.2 \%$ below the ploughing depth, but showed little effect on the soil bulk density. Compaction compressed the soil and effectively increased the bulk density from 1.51 to $1.61 \mathrm{~g} \mathrm{~cm}^{-3}$. Compared with the combination of ploughing and compaction, the weight percentage of clay content increases from 6.2 to $14.8 \%$ and the bulk density increases from 1.51 to $1.71 \mathrm{~g} \mathrm{~cm}^{-3}$ at $2 \mathrm{~cm}$ above the ploughing depth after 14 cultivation practices.

The experimental results suggested that clay is an essential factor for creating a less permeable plough sole and reducing the infiltration rate. As long as clay particles remain in the paddy field, laboratory results suggest that a plough sole can be reformed after ploughing and compacting the soil 14 times, and this result needs to be validated in the field setting. In normal conditions if there are four ploughing activities per year, then it will take approximately 3 years to recreate the original plough sole conditions. If the water conservation is critical, the farmer may perform all 14 operations in succession to reform the plough sole before planting the first crop. The results of this study presented here provide valuable information on how to rehabilitate plough soles that have been removed.

\section{Acknowledgments}

The writers would like to thank the Tsao-Jiin Memorial Foundation and the Council of Agriculture of the Republic of China for financially supporting this research under Contract No. 89-NOUFAR-11.1-LIN-02 (06).

\section{References}

Chen, S. K., and Liu, C. W. (2002). "Analysis of water movement in the paddy field (I). Experimental studies." J. Hydrol., 260(1-4), 206-215.

Council of Agriculture (COA). (2000). Agriculture year book, COA, Taipei, Taiwan.

Curfs, H. P. F. (1976). "Systems development in agricultural mechanization with special reference to soil tillage and weed control." Rep. No. 76-5, Agricultural University, Wageningen, The Netherlands.

De Datta, S. K. (1981). Principles and practices of rice production, Wiley, New York.

Feng, C. S., Hsu, R. T., Lee, C. K., and Hsu, S. S. (1996). "Ground water recharge from flooded paddy in Chia-Nan plain (II)." Rep. No. 189, Hydraulic Experimental Laboratory, National Chung-Kung Univ., Tania, Taiwan.

Feng, C. S., Hsu, R. T., Lu, R. Y., Chou, Y. Z., and Hsu, S. S. (1995). "Ground water recharge from flooded paddy in Chia-Nan plain (I)." Rep. No. 172, Hydraulic Experimental Laboratory, National ChungKung Univ., Tania, Taiwan.

Ghidyal, B. P. (1978). "Effects of compaction and puddling on soil physical properties and rice growth." Soils and rice, IRRI, Los Banos, Philippines, 317-336.

Ghildyal, B. P., and Satyanarayana, T. (1965). "Effect of compaction on physical properties of four soils of India." J. Indian Soc. Soil Sci., 13, 149-155.

Herzig, J. P., Leclerc, D. M., and Le Goff, P. (1970). "Flow of suspensions through porous media-Application to deep filtration." Ind. Eng. Chem., 62(5), 8-35. 
Iwata, S., Tabuchi, T., and Warkentin, B. P. (1995). Soil-water interactions: Mechanisms and applications, Marcel Dekker, New York.

Liu, C. W., and Chen, S. K. (1998). Evaluation of alternative strategies for increasing groundwater recharge from rice paddy field: Infiltration and classification of the contribution to non-irrigated-area groundwater recharge, Bureau of Hydraulics, Taiwan.

Liu, C. W., Chen, S. K., Jou, S. W., and Kuo, S. F. (2001). "Estimation of the infiltration rate of paddy in Yun-Lin, Taiwan.” Agric. Syst., 68(1), 41-54.

McDowell-Boyer, L. M., Hunt, J. R., and Sitar, N. (1986). "Particle transport through porous media." Water Resour. Res., 22(13), 1901-1921.

Moormann, F. R., and Van Breemen, N. (1978). Rice: soil, water, land, International Rice Research Institute, Los Banos, Philippines.

Sakthivadivel, R. (1969). "Clogging of granular porous medium by sediment." Rep. No. HEL 15-7, Hydraulic Engineering Laboratory, Univ. of California at Berkeley, Berkeley, Calif.

Sharma, P. K., and De Datta, S. K. (1985). "Effects of pudding on soil physical properties and processes." Soil physics and rice, International
Rice Research Institute, Los Banos, Philippines, 337-357.

Sherard, J. L., Dunnigan, L. P., and Talbot, J. R. (1984). "Filters for silts and clays." J. Geotech. Eng., 110(6), 701-718.

Swan, J. B., Moncrief, J. F., and Voorhees, W. B. (1993). Soil compaction-causes, effects and control, Univ. of Minnesota, Minneapolis.

Ting, C. S., Liao, C. J., and Lin, L. H. (1998). Investigation of the groundwater recharge from irrigation water in rice paddies, Tsao-Jiin Memorial Foundation, Kao-Shuing, Taiwan.

Tzia, M. H. (2000). Sustainable development of irrigation and drainage for rice paddy fields in Taiwan, Council of Agriculture, Taiwan.

Wopereis, M. C. S., Bouman, B. A. M., Kropff, M. J., ten Berge, H. F. M., and Maligaya, A. R. (1994). "Water use efficiency of flooded rice fields. (I) Validation of soil-water balance model SAWAH." Agric. Water Manage., 26(3), 277-289.

Wopereis, M. C. S., Wosten, J. H. M., Bouman, J., and Woodhead, T. (1992). "Hydraulic resistance in puddle rice soils: measurement and effects on water movement." Soil Till. Res., 24(3), 199-209. 